\title{
Fabrication and Characterization of MCC Approved Testing Material-ATM-1 Glass
}

J.W. Wald

October 1985

Prepared for the U.S. Department of Energy under Contract DE-AC06-76RLO 1830

Pacific Northwest Laboratory Operated for the U.S. Department of Energy by Battelle Memorial Institute 


\title{
DISCLAIMER
}

This report was prepared as an account of work sponsored by an agency of the United States Government. Neither the United States Government nor any agency thereof, nor any of their employees, makes any warranty, express or implied, or assumes any legal liability or responsibility for the accuracy, completeness, or usefulness of any information, apparatus, product, or process disclosed, or represents that its use would not infringe privately owned rights. Reference herein to any specific commercial product, process, or service by trade name, trademark, manufacturer, or otherwise, does not necessarily constitute or imply its endorsement, recommendation, or favoring by the United States Government or any agency thereof. The views and opinions of authors expressed herein do not necessarily state or reflect those of the United States Government or any agency thereof.

\author{
PACIFIC NORTHWEST LABORATORY \\ operated by \\ BATTELLE \\ for the \\ UNITED STATES DEPARTMENT OF ENERGY \\ under Contract DE-AC06-76RLO 1830
}

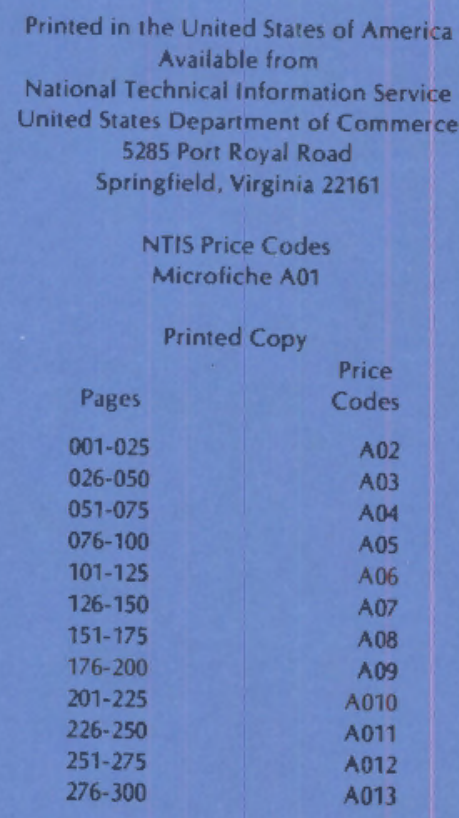


J. W. Wald

October 1985

Prepared for

the U.S. Department of Energy

under Contract DE-AC06-76RLO 1830

Pacific Northwest Laboratory

Richland, Washington 99352 


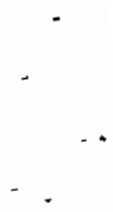


This report, prepared by the Materials Characterization Center, is one in a series of PNL-5577 reports on the MCC's nuclear waste glass Approved Testing Materials (ATMs). The suffix number shows the specific ATM described (e.g., ATM-1 is the subject of PNL-5577-1; ATMs $-2,-3$ and -4 are included in PNL-5577-2,3,4; etc.). Additional reports will be added to the series as the corresponding glass ATMs are produced by MCC. For a summary of existing ATMs, see the most recent issue of PNL-4955, Approved Reference and Testing Materials for Use in Nuclear Waste Management Research and Development Programs. PNL-4955-2 (Mellinger and Daniel) was issued in December 1984.

The series currently planned includes the following reports:

\begin{tabular}{|c|c|}
\hline Report No. & Subject Glass \\
\hline PNL-5577-1 & ATM-1 \\
\hline PNL-5577-2,3,4 & ATM-2, ATM-3, ATM-4 \\
\hline PNL-5577-5 & ATM-5 \\
\hline PNL-5577-6 & ATM-6 \\
\hline PNL-5577-8 & ATM- 8 \\
\hline PNL-5577-9 & ATM -9 \\
\hline PNL-5577-10 & ATM-10 \\
\hline PNL-5577-11 & ATM- 11 \\
\hline PNL $-5577-12$ & ATM-12 \\
\hline PNL-5577-18 & ATM- 18 \\
\hline
\end{tabular}



CONTENTS

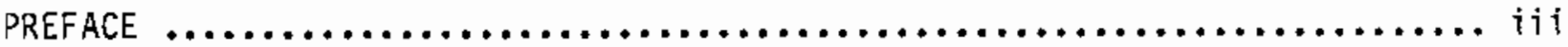

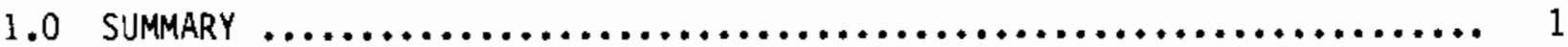

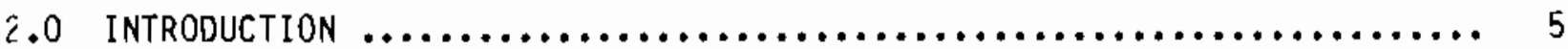

3.0 FABRICATION $\ldots \ldots \ldots \ldots \ldots \ldots \ldots \ldots \ldots \ldots \ldots \ldots \ldots \ldots \ldots \ldots \ldots \ldots \ldots, 7$

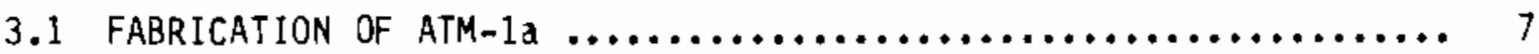

3.1.1 Starting Materials $\ldots \ldots \ldots \ldots \ldots \ldots \ldots \ldots \ldots \ldots \ldots \ldots, 7$

3.1.2 Batch and Glass Preparation $\ldots \ldots \ldots \ldots \ldots \ldots \ldots \ldots \ldots, 7$

3.1.3 Measurement and Testing Equipment $\ldots \ldots \ldots \ldots \ldots \ldots \ldots \ldots . .10$

3.1 .4 Other Equipment $\ldots \ldots \ldots \ldots \ldots \ldots \ldots \ldots \ldots \ldots \ldots \ldots \ldots, 10$

3.1 .5 Procedures $\ldots \ldots \ldots \ldots \ldots \ldots \ldots \ldots \ldots \ldots \ldots \ldots \ldots \ldots, 11$

3.1 .6 Identification System $\ldots \ldots \ldots \ldots \ldots \ldots \ldots \ldots \ldots \ldots \ldots, 11$

3.1.7 Material Availability and Storage $. . \ldots \ldots \ldots \ldots \ldots \ldots \ldots, 11$

3.2 FABRICATION OF ATM-16 $\ldots \ldots \ldots \ldots \ldots \ldots \ldots \ldots \ldots \ldots \ldots \ldots \ldots \ldots, 12$

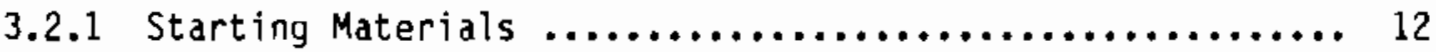

3.2.2 Batch and Glass Preparation $\ldots \ldots \ldots \ldots \ldots \ldots \ldots \ldots \ldots \ldots, 12$

3.2.3 Measurement and Testing Equipment $\ldots \ldots \ldots \ldots \ldots \ldots \ldots \ldots, 14$

3.2 .4 Other Equipment $\ldots \ldots \ldots \ldots \ldots \ldots \ldots \ldots \ldots \ldots \ldots \ldots \ldots \ldots, 14$

3.2 .5 Procedures $\ldots \ldots \ldots \ldots \ldots \ldots \ldots \ldots \ldots \ldots \ldots \ldots \ldots \ldots \ldots, 15$

3.2.6 Identification System $\ldots \ldots \ldots \ldots \ldots \ldots \ldots \ldots \ldots \ldots \ldots \ldots, 15$

3.2.7 Material Availability and Storage $\ldots \ldots \ldots \ldots \ldots \ldots \ldots \ldots . \ldots . \ldots . \ldots$

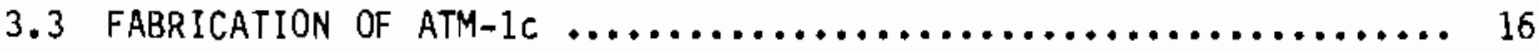

3.3.1 Starting Materials $\ldots \ldots \ldots \ldots \ldots \ldots \ldots \ldots \ldots \ldots \ldots \ldots \ldots, 16$

3.3.2 Batch and Glass Preparation $. . . \ldots \ldots \ldots \ldots \ldots \ldots \ldots \ldots . . .16$ 
3.3.2.1 Preparation of Special forms $\ldots \ldots \ldots \ldots \ldots \ldots . \ldots 18$

3.3 .2 .1 .1 Crushed and Sized Powder .......... 18

3.3.2.1.2 Uncased Discs and Cylinders ........ 19

3.3.2.1.3 Stainless Steel Clad Discs

and Cylinders ..................... 19

3.3.2.1.4 Tapered Cast Cylinders ............ 20

3.3.3 Measurement and Testing Equipment $\ldots \ldots \ldots \ldots \ldots \ldots \ldots \ldots . \ldots 21$

3.3 .4 0ther Equipment $\ldots \ldots \ldots \ldots \ldots \ldots \ldots \ldots \ldots \ldots \ldots \ldots \ldots \ldots \ldots . \ldots 1$

3.3 .5 Procedures $\ldots \ldots \ldots \ldots \ldots \ldots \ldots \ldots \ldots \ldots \ldots \ldots \ldots \ldots \ldots \ldots \ldots . \ldots \ldots$

3.3.6 Identification System $\ldots \ldots \ldots \ldots \ldots \ldots \ldots \ldots \ldots \ldots \ldots \ldots \ldots 21$

3.3.7 Material Availability and Storage $\ldots \ldots \ldots \ldots \ldots \ldots \ldots . \ldots 22$

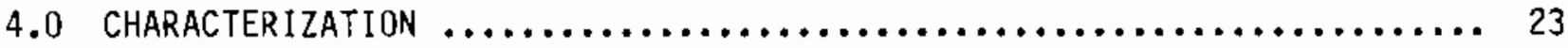

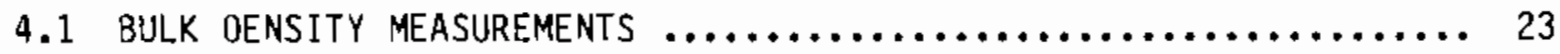

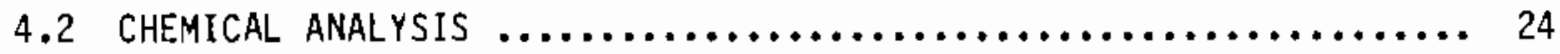

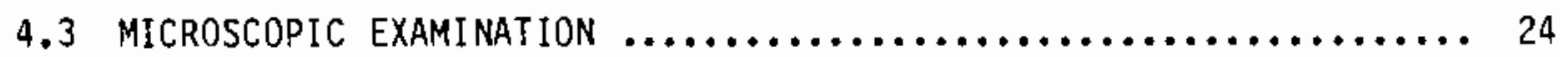

$4.4 \quad X$-RAY DIFFRACTION ANALYSIS $\ldots \ldots \ldots \ldots \ldots \ldots \ldots \ldots \ldots \ldots \ldots \ldots \ldots \ldots \ldots$

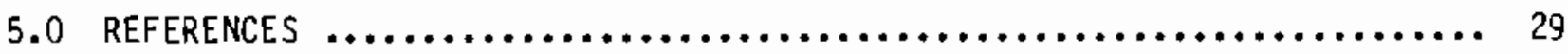


FIGURES

4.1 Typical Microstructure of G1 ass ATM-1 $\ldots \ldots \ldots \ldots \ldots \ldots \ldots \ldots \ldots \ldots, 26$

\section{TABLES}

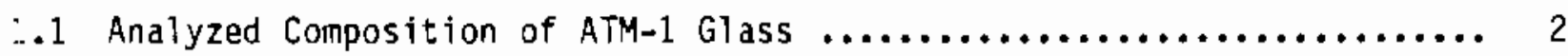

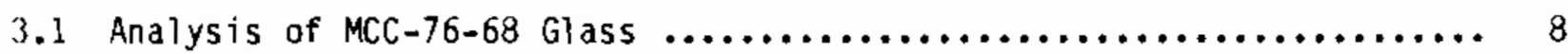

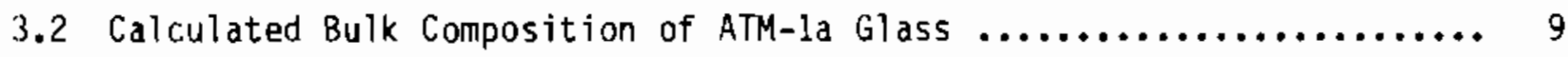

3.3 Product Sumary for ATM-1a Glass $\ldots \ldots \ldots \ldots \ldots \ldots \ldots \ldots \ldots \ldots \ldots \ldots . \ldots \ldots$

3.4 Calculated Bulk Composition of ATM-lb Glass $\ldots \ldots \ldots \ldots \ldots \ldots \ldots \ldots . . \ldots$

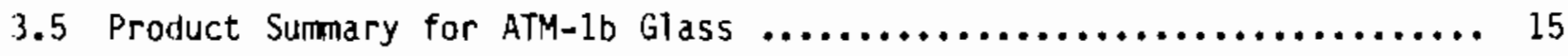

3.6 Requested Oxide Composition of ATM-1c Glass $\ldots \ldots \ldots \ldots \ldots \ldots \ldots \ldots, 17$

3.7 Special Form Requirements Requested by NNWSI for
MCC ATM-1C Glass $\ldots \ldots \ldots \ldots \ldots \ldots \ldots \ldots \ldots \ldots \ldots \ldots \ldots \ldots \ldots \ldots \ldots \ldots \ldots \ldots \ldots$

4.1 Measured Bulk Density of ATM-1 Glass $\ldots \ldots \ldots \ldots \ldots \ldots \ldots \ldots \ldots \ldots . \ldots \ldots$

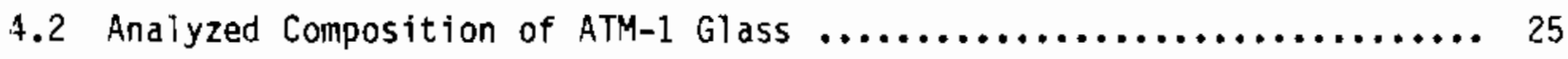

4.3 Summary of $X$-ray Diffraction Analyses of ATM-1 $\ldots \ldots \ldots \ldots \ldots \ldots \ldots . \ldots 27$ 



\subsection{SUMMARY}

The Materials Characterization Center (MCC) Approved Testing Material ATM-1 is a borosilicate glass that incorporates nonradioactive constituents and uranium to represent high-level waste (HLW) resuiting from the reprocessing of comnercial nuclear reactor fuel. Its composition is based upon the simulated HLW glass type 76-68 (Mendel et al. 1977) to which depleted uranium has been added as $\mathrm{UO}_{2}$. Three separate lots of ATM-1 glass have been fabricated, designated ATM-1a, ATM-lb, and ATM-1C. These individual lots were made by the MCC at the Pacific Northwest Laboratory (PNL) operated for the Department of Energy (DOE) by Battelle Memorial Institute. The lots were made in the years 1982 , 1983, and 1984, respectively. Limited analyses and microstructural evaluations were conducted on each type during 1984.

Each lot of ATM-1 glass was produced from a feedstock melted in an air atmosphere at between $1150-1200^{\circ} \mathrm{C}$ in platinum crucibles and cast into stress annealed rectangular bars. Bars of ATM-1a were nominally $1.3 \times 1.3 \times 7.6 \mathrm{~cm}$ ( $36 \mathrm{~g} \mathrm{each),} \mathrm{bars} \mathrm{of} \mathrm{ATM-lb} \mathrm{were} \mathrm{nominally} 2 \times 2.5 \times 17.5 \mathrm{~cm}(\sim 190 \mathrm{~g}$ each) and bars of ATM-1C were nominally $1.9 \times 1.9 \times 15 \mathrm{~cm}(\sim 170 \mathrm{~g}$ each). Thirteen bars of ATM-1a, 14 bars of ATM-1b, and 6 bars of ATM-1c (used to produce special forms) were produced.

Table 1.1 lists the analyzed composition of 12 random samples from each of lots ATM-1a, ATM-1b, and ATM-1c. The concentrations (except for $U$ and Cs) were obtained by Inductively-Coupled Argon Plasma Atomic Emission Spectroscopy (ICP) analysis. Cesium analysis was performed by Atomic Absorption Spectroscopy (AA), while uranium was analyzed by Pulsed Laser Fluorometry. X-ray diffraction (XRD) analysis of four samples randomly obtained from each lot indicated that lot ATM-la had no detectable crystalline phases ( $<3 w$ t $\%$, while ATM-1b and ATM-1c contained $3-5$ wt\% (just above estimated detection level) iron-chrome spinel crystals. These concentrations of secondary spinel component are not considered uncommon in this particular borosilicate glass composition. Scanning electron microscopy (SEM) examination of fracture surfaces of random samples from each lot revealed only a random, apparentiy crystalline, second phase (1 to $10 \mu \mathrm{m}$ diameter) and a random distribution of small voids or bubbles ( $\sim 1$ um nominal diameter). 
TABLE 1.1. Analyzed Composition of ATM-1 Glass(a)

\begin{tabular}{|c|c|c|c|c|c|c|}
\hline \multirow[b]{2}{*}{ Oxide } & \multicolumn{2}{|c|}{ ATM-la } & \multicolumn{2}{|c|}{ ATM-1b } & \multicolumn{2}{|c|}{ ATM-1c } \\
\hline & $w t \%$ & $\begin{array}{l}\text { Standard } \\
\text { Oeviation }\end{array}$ & $w t \%$ & $\begin{array}{l}\text { Standard } \\
\text { Oeviation }\end{array}$ & wt\% & $\begin{array}{l}\text { Standard } \\
\text { Deviation }\end{array}$ \\
\hline $\mathrm{Ag}_{2} \mathrm{O}$ & $\Longrightarrow N A$ & NA- & NA & -- & & \\
\hline $\mathrm{Al}_{2} \mathrm{O}_{3}$ & 0.64 & 0.03 & 0.85 & 0.02 & 0.58 & 0.02 \\
\hline $\mathrm{B}_{2} \mathrm{O}_{3}$ & 8.47 & 0.31 & 8.55 & 0.08 & 9.07 & 0.07 \\
\hline $8 a 0$ & 0.50 & 0.02 & 0.62 & 0.00 & 0.54 & 0.00 \\
\hline $\mathrm{Ca} 0$ & 1.99 & 0.99 & 2.11 & 0.03 & 2.23 & 0.02 \\
\hline $\mathrm{CdO}$ & 0.04 & 0.00 & 0.04 & 0.00 & 0.04 & 0.00 \\
\hline $\mathrm{CeO}_{2}$ & 0.88 & 0.03 & 0.97 & 0.09 & 0.90 & 0.03 \\
\hline $\mathrm{Cr}_{2} \mathrm{O}_{3}$ & 0.39 & 0.02 & 0.45 & 0.04 & 0.42 & 0.01 \\
\hline $\operatorname{Cs}_{2}{ }^{\circ}$ & 0.71 & 0.04 & 0.77 & 0.02 & $0.7 \mathrm{~B}$ & 0.05 \\
\hline $\mathrm{Dy}_{2} \mathrm{O}_{3}$ & $<\mathrm{OL}, \quad 0.01$ & -- & $<D L, 0.01$ & -- & $<D L, 0.01$ & - \\
\hline $\mathrm{Eu}_{2} \mathrm{O}_{3}$ & NA & -- & NA & -. & NA & -- \\
\hline $\mathrm{Fe}_{2} \mathrm{O}_{3}$ & 8.16 & 0.29 & 8.16 & 0.04 & 8.70 & 0.05 \\
\hline $\mathrm{Gd}_{2} \mathrm{O}_{3}$ & $\angle D L, 0.03$ & $=$ & $\angle D L, 0.03$ & $=$ & $\angle D L, 0.03$ & $=$ \\
\hline $\mathrm{K}_{2}{ }^{-}$ & 0.56 & 0.29 & 0.56 & 0.15 & 0.73 & 0.13 \\
\hline $\mathrm{La}_{2} \mathrm{O}_{3}$ & 4.00 & 0.19 & 5.07 & 0.02 & 4.39 & 0.03 \\
\hline $\mathrm{Mg} 0$ & 0.30 & 0.00 & 0.30 & 0.01 & 0.24 & 0.02 \\
\hline $\mathrm{MnO}_{2}$ & 0.03 & 0.00 & 0.03 & 0.00 & 0.03 & 0.00 \\
\hline $\mathrm{MoO}_{3}^{2}$ & 1.72 & 0.08 & 1.99 & 0.03 & 1.82 & 0.01 \\
\hline $\mathrm{Na}_{2} \mathrm{O}$ & 10.14 & 0.43 & 9.66 & 0.08 & 10.51 & 0.10 \\
\hline $\mathrm{Nd}_{2} \mathrm{O}_{3}$ & 1.34 & 0.05 & 1.61 & 0.03 & 1.42 & 0.01 \\
\hline $\mathrm{N} \mp \mathrm{O}$ & 0.18 & 0.01 & 0.22 & 0.03 & 0.20 & 0.01 \\
\hline$P_{2} O_{5}$ & 0.63 & 0.05 & 0.60 & 0.06 & 0.60 & 0.06 \\
\hline Pdo & NA & -- & NA & $=$ & NA & -. \\
\hline $\mathrm{Rh}_{2} \mathrm{O}_{3}$ & NA & - & NA & - & NA & $\rightarrow$ \\
\hline $\mathrm{RuO}_{2}$ & NA & - & NA & $\cdots$ & NA & - \\
\hline $\mathrm{SiO}_{2}^{2}$ & 38.73 & 1.35 & 40.50 & 0.28 & 41.2 & 0.03 \\
\hline $\mathrm{Sm}_{2} \mathrm{O}_{3}$ & NA & -- & NA & -- & NA & -- \\
\hline Sro & 0.37 & 0.01 & 0.46 & 0.01 & 0.40 & 0.005 \\
\hline $\mathrm{TeO}_{2}$ & NA & -- & NA & -- & NA & -- \\
\hline $\mathrm{TiO}_{2}^{2}$ & 2.62 & 0.09 & 2.60 & 0.01 & 2.82 & 0.02 \\
\hline $\mathrm{UO}_{2}$ & 3.98 & 0.11 & 4.16 & 0.08 & 4.02 & 0.08 \\
\hline $\mathrm{Y}_{2} \mathrm{O}_{3}$ & $N A$ & -- & NA & -- & NA & -- \\
\hline $\operatorname{Zn} 0^{\circ}$ & 4.15 & 0.15 & 4.34 & 0.03 & 4.46 & 0.04 \\
\hline $\mathrm{ZrO}_{2}$ & 1.46 & 0.05 & 1.88 & 0.06 & 1.54 & 0.09 \\
\hline Total & 91.99 & & 96.50 & & 97.64 & \\
\hline
\end{tabular}

(a) Based on analysis of 12 random samples for each batch; standard deviations for an individual analysis.

$N A=$ Not analyzed.

$\angle O L=$ Below the detection limit indicated. 
While the precision of the analyses shown in Table l.l is satisfactory, the accuracy of individual values is uncertain, since the summation is significantly less than $100 \%$. Additional analyses by other laboratories and methods are in progress.

Material from the three lots of ATM-1 glass has been made available to several waste management programs. As of August 1985 the remaining quantities of material sti1l available for distribution are: ATM-1a, 127 g; ATM-1b, $1679 \mathrm{~g}$; ATM-1C, no material available. Requests for materials or services related to this glass should be directed to the Materials Characterization Center Program office, PNL. 


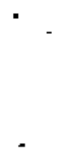




\subsection{INTRODUCTION}

The objective of the MCC is to assist the DOE projects responsible for nuclear waste form production, transportation, and disposal to assemble a materials database of defensible precision and accuracy. A major responsibility of the MCC is to arrange for the formulation, acquisition and distribution of reference and testing materials essential for quantitative evaluation of nuclear waste forms and repository systems under development in the U.S. The purpose of this document is to provide the fabrication and characterization details of the Approved Test Material (ATM) ATM-1 glass, which was prepared under the MCC charter.

ATM-1 is a borosilicate glass that incorporates nonradioactive constituents and uranium to represent high-level waste ( $\mathrm{HLW}$ ) resulting from the reprocessing of commercial nuclear reactor fuels. Its composition is based upon the simulated HLW glass type 76-68 (Mendel et al. 1977) to which depleted uranium has been added. Three separate lots of ATM-l were fabricated at different times; the lots are designated ATM-1a, ATM-1b, and ATM-1C in accordance with fabrication order. ATM-1a was prepared at the Pacific Northwest Laboratory (PNL) in December of 1982 at the request of the Salt Repository Investigations Program at PNL for use in testing at PNL in support of the Office of Nuclear waste Isolation (ONWI). ATM-1b was prepared at PNL in January of 1983 at the request of the Tuff Repository Investigations Project at PNL for use in testing at PNL in support of the Nevada Nuclear Waste Storage Investigations (NNWSI). ATM-1C was produced at PNL in February of 1984 at the request of NNWSI staff at Lawrence Livermore National Laboratory, Livermore, California. Special castings and crushed material were produced for NNWSI from ATM-1C for use in their repository development testing program. Instructions and information on these special forms were provided to the MCC by NNWSI staff in private correspondence.

Section 3 of this report describes the fabrication of the three lots of ATM-1 glass, and Section 4 sumarizes the analysis and characterization of the final glass product. The glass lots reported here were produced under the guidance of the MCC Program Quality Assurance (QA) Plan PGM-4, Rev. 2, and PNL 
QA Plan PNL-MA-65, which were in effect during the course of this work. No written technical procedures were prepared specifically for the fabrication and characterization of these glass lots. The procedures followed were fully documented in official laboratory record books, as required in the previously listed QA plans. 


\subsection{FABRICATION (a)}

\subsection{FABRICATION OF ATM-1a}

The fabrication of ATM-la glass began on December 20, 1982 and was completed by December 29, 1982. All work involved in the fabrication of this glass took place in Lab 208, 308 Building, 300 Area. ATM-la was prepared from crushed type 76-68 glass to which depleted uranium dioxide was added.

\subsubsection{Starting Materials}

The glass which served as the feedstock for ATM-1a was MCC-76-68, Lot 3, bar numbers 265,276, 281, 307 and 309. The MCC-76-68 glass was produced for PNL by Penberthy Electromelt of Seattle, Washington under purchase order number A2820/A2823AF and received at PNL in September 1980. The average analyzed composition of lot 3 of the MCC-76-68 glass used for ATM-1a is given in Table 3.1; no specific analyses were conducted on the $5 \mathrm{glass}$ bars used to produce ATM-la. Depleted uranium was added as a nitrate solution for the formulation of ATM-la. The source of the $\mathrm{UO}_{2}$ additive was from on-hand stock of $0.15 \% 235 \mathrm{U}$ material. No other historical or analytical information is available for the $10_{2}$ additive.

\subsubsection{Batch and Glass Preparation}

Table 3.2 lists the calculated oxide composition of ATM-la glass based on a 3.98 wt\% addition of $\mathrm{UO}_{2}$ to the $\mathrm{MCC}-76-68$, Lot 3 glass. The batching process was conducted as follows:

- Five bars of MCC-76-68, Lot 3 glass, were crushed, ground, and sieved to -100 mesh $(-150 \mu m)$ using an agate chamber laboratory disc mill (Angstrom), and Newark stainless steel sieves. All material (-100 mesh) was combined into a single container and tumble blended to assure uniformity of mixture.

(a) The use of trade and manufacturers' names in this report is for documentation purposes only and does not imply endorsement by PNL. 
TABLE 3.1. Analysis of MCC-76-6B Glass (a)

\begin{tabular}{|c|c|c|c|c|}
\hline \multirow[b]{3}{*}{ Oxide $(\mathrm{d})$} & \multicolumn{2}{|c|}{ Glass ATM- $1 b$ ) } & \multicolumn{2}{|c|}{ ATM-la and ATM-1C) } \\
\hline & \multicolumn{2}{|c|}{ Concentration, wt\% (b) } & \multicolumn{2}{|c|}{ Concentration, wto(b) } \\
\hline & $w t \%$ & $\begin{array}{c}\text { Standard } \\
\text { Deviation }(c)\end{array}$ & $\mathrm{wt} \%$ & $\begin{array}{c}\text { Standard } \\
\text { Deviation }(c)\end{array}$ \\
\hline $\mathrm{Al}_{2} \mathrm{O}_{3}$ & 0.84 & 0.03 & 0.59 & 0.02 \\
\hline $\mathrm{B}_{2} \mathrm{O}_{3}$ & 8.65 & 0.06 & 9.06 & 0.01 \\
\hline BaO & 0.62 & 0.01 & 0.55 & 0.00 \\
\hline $\mathrm{CaO}$ & 2.29 & 0.04 & 2.37 & 0.04 \\
\hline $\mathrm{CdO}$ & 0.05 & 0.01 & 0.05 & 0.01 \\
\hline $\mathrm{CeO}_{2}$ & $<0.02$ & -. & 0.92 & 0.01 \\
\hline $\mathrm{C} r 2_{3} \mathrm{O}_{3}$ & $D .50$ & 0.02 & 0.47 & 0.01 \\
\hline $\mathrm{Cs}_{2} \mathrm{O}^{\circ}$ & 1.21 & 0.08 & 1.11 & 0.06 \\
\hline $\mathrm{Dy}_{2} \mathrm{O}_{3}$ & 0.01 & 0.00 & 0.01 & D. 00 \\
\hline $\mathrm{Eu}_{2} \mathrm{O}_{3}$ & 0.01 & 0.00 & 0.01 & 0.00 \\
\hline $\mathrm{Fe}_{2} \mathrm{O}_{3}$ & 9.08 & 0.12 & 9.56 & 0.13 \\
\hline $\mathrm{Gd}_{2} \mathrm{O}_{3}$ & 0.03 & 0.01 & 0.02 & 0.00 \\
\hline $\mathrm{K}_{2} \mathrm{O}^{\circ}$ & 0.09 & 0.03 & $<0.06$ & $-\cdots$ \\
\hline $\mathrm{La}_{2} \mathrm{O}_{3}$ & 4.89 & 0.06 & 4.16 & 0.05 \\
\hline $\mathrm{MgO}$ & 0.18 & 0.01 & 0.16 & 0.01 \\
\hline $\mathrm{MnO}_{2}$ & 0.06 & 0.00 & 0.06 & 0.01 \\
\hline $\mathrm{MoO}_{3}$ & 2.17 & 0.01 & 1.97 & 0.03 \\
\hline $\mathrm{Na}_{2} \mathrm{O}$ & 11.60 & 0.95 & 12.77 & 1.21 \\
\hline $\mathrm{Nd}_{2} \mathrm{O}_{3}$ & 1.65 & 0.01 & 1.41 & 0.02 \\
\hline $\mathrm{Ni}_{\mathrm{O}} \mathrm{O}$ & 0.25 & 0.03 & 0.23 & 0.01 \\
\hline $\mathrm{P}_{2} \mathrm{O}_{5}$ & 0.56 & 0.08 & 0.80 & 0.16 \\
\hline $\mathrm{SiO}_{2}$ & 40.33 & 0.81 & 42.00 & 0.26 \\
\hline SrO & 0.49 & 0.01 & 0.42 & 0.01 \\
\hline $\mathrm{TiO}_{2}$ & 2.86 & 0.04 & 3.08 & 0.05 \\
\hline $2 n 0^{\circ}$ & 4.75 & 0.08 & 5.10 & 0.46 \\
\hline $\mathrm{ZrO}_{2}$ & 2.33 & 0.04 & 1.89 & 0.04 \\
\hline TOTAL & 95.50 & & 98.76 & \\
\hline
\end{tabular}

(a) See Table 12, Mellinger and Daniel, 1984.

(b) Based on ICP analysis of three bars from the 100 bars comprising each lot.

(c) Standard Deviation of an individual analysis.

(d) Oxides listed were components of fabrication specifications for MCC-76-68. Other oxides of interest for ATM-1C glass, neither added to $\mathrm{MCC}-76-68$ nor analyzed, include $\mathrm{Ag}_{2} \mathrm{O}, \mathrm{PdO}, \mathrm{Rh}_{2} \mathrm{O}_{3}, \mathrm{RuO}_{2}, \mathrm{Sm}_{2} \mathrm{O}_{3}, \mathrm{TeO}_{2}$, $\mathrm{Y}_{2} \mathrm{O}_{3}$, and $\mathrm{UO}_{2}$. 
TABLE 3.2. Calculated Bulk Composition of Glass ATM-1a (a)

\begin{tabular}{|c|c|}
\hline Oxide & wt\% \\
\hline $\mathrm{Al}_{2} \mathrm{O}_{3}$ & 0.57 \\
\hline $\mathrm{B}_{2} \mathrm{O}_{3}$ & 8.81 \\
\hline $\mathrm{BaO}$ & 0.53 \\
\hline $\mathrm{CaO}$ & 2.30 \\
\hline $\mathrm{CdO}$ & 0.05 \\
\hline $\mathrm{CeO}_{2}$ & 0.89 \\
\hline $\mathrm{Cr}_{2} \mathrm{O}_{3}$ & 0.46 \\
\hline $\mathrm{Cs}_{2} \mathrm{O}^{\circ}$ & 1.08 \\
\hline $\mathrm{Dy}_{2} \mathrm{O}_{3}$ & 0.01 \\
\hline $\mathrm{Eu}_{2} \mathrm{O}_{3}$ & 0.01 \\
\hline $\mathrm{Fe}_{2} \mathrm{O}_{3}$ & 9.29 \\
\hline $\mathrm{Gd}_{2} \mathrm{O}_{3}$ & 0.02 \\
\hline $\mathrm{K}_{2} \mathrm{O}^{\circ}$ & $<0.06$ \\
\hline $\mathrm{La}_{2} \mathrm{O}_{3}$ & 4.04 \\
\hline $\mathrm{MgO}$ & 0.16 \\
\hline $\mathrm{MnO}_{2}$ & 0.06 \\
\hline $\mathrm{MOO}^{\circ}$ & 1.92 \\
\hline $\mathrm{Na}_{2} \mathrm{O}$ & 12.42 \\
\hline $\mathrm{Nd}_{2} \mathrm{O}_{3}$ & 1.37 \\
\hline $\mathrm{NiO}$ & 0.22 \\
\hline $\mathrm{P}_{2} \mathrm{O}_{5}$ & 0.78 \\
\hline $\mathrm{SiO}_{2}$ & 40.83 \\
\hline Sro & 0.41 \\
\hline $\mathrm{TiO}_{2}$ & 2.99 \\
\hline $\mathrm{UO}_{2}{ }^{2}$ & 3.98 \\
\hline $\ln 0$ & 4.96 \\
\hline $\mathrm{ZrO}_{2}$ & 1.84 \\
\hline TOTAL & 100.00 \\
\hline
\end{tabular}

(a) Based on addition of uranium oxide to the oxide concentration values shown in Table 3.1 (Lot 3), and normalization to $100 \%$. See Table 3.1, footnote $d$. 
- $432.08 \mathrm{~g}$ of crushed glass was weighed out and mixed with a nitrate solution containing $17.92 \mathrm{~g} \mathrm{vO}_{2}$ powder dissolved in $30 \mathrm{~mL}$ of concentrated $\mathrm{HNO}_{3}$ and diluted to a final solution volume of $120 \mathrm{~mL}$ using deionized water. A target ratio (dopant solution to glass powder) of 25-30 $\mathrm{mL}$ per $100 \mathrm{~g}$ was sought.

- All glass powder was wetted by the dopant uranium nitrate solution allowing a uniform blending of the slurry by hand stirring. Mix time was approximately 5 minutes. The slurry mixture was dried in a single batch contained in a Pyrex beaker on a conventional hot plate. Total drying time was approximately 4 hours at about $200^{\circ} \mathrm{C}$.

- A hardened steel punch and die was used to crush and grind the doped and dried glass mixture by hand to a -20 mesh $(-850 \mathrm{~m})$ particle size prior to melting. The batch was melted in a single Pt crucible at $1200^{\circ} \mathrm{C}$ in an air atmosphere for 5-10 minutes prior to bar pouring. Each melt was mixed just prior to pouring by swirling and agitating the crucible. The molten glass batch was poured into a preheated $\left(\sim 500^{\circ} \mathrm{C}\right)$ steel bar mold (nominal dimensions $1.3 \times 1.3 \times 7.6 \mathrm{~cm}$ ), allowed to cool enough to facilitate handling, and placed into an annealing furnace at $500^{\circ} \mathrm{C}$, held for 2 hours and furnace cooled at $\sim 175^{\circ} \mathrm{C} / \mathrm{h}$ to $25^{\circ} \mathrm{C}$. Three separate melting runs were required to produce the initial 13 bars that were formed.

\subsubsection{Measurement and Testing Equipment}

Fluke Digital Thermometer, Model No. 2190A/Y2001; CALIB. \$364-79-06-007

Sartorious Balance, Model No. 202MP; CALIB. \$364-06-01-011

Mettler Balance, Model No. HK-160; CAL IB. \#364-06-01-010

\subsubsection{Other Equipment}

Deltec DT-31 Furnace

Lindberg Lightweight Box furnace

Angstrom Laboratory Disc Mill, with agate grinding chamber

Corning $\mathrm{PC}-354$ Hot Plate 


\subsubsection{Procedures}

MCC-SP-1 (Draft): Glass Component Preparation

MCC-SP-2 (Draft): Glass Preparation

RWP-308-1, Rev. 14: Lab Specific, General Radiation Work Procedure

\subsubsection{Identification System}

Glass bars poured in this fabrication work were individually numbered, independent of the pouring order. Bars from this preparation were initially labeled U1 through U13 but have been relabeled ATM-1a-1 through ATM-1a-13. Thirteen bars total were produced with three sizes as follows: 10 each at $1.3 \times 1.3 \times 7.6 \mathrm{~cm} ; 2$ each at $1.3 \times 1.3 \times 5.1 \mathrm{~cm} ; 1$ at $1.3 \times 1.3 \times 2.5 \mathrm{~cm}$. Production records for this glass are recorded on Page 14 of PNL Laboratory Record Book BNW-3660. Table 3.3 gives the initial and final ID numbers and mass of the bars.

\subsubsection{Material Availability and Storage}

As of August 1985, approximately $127 \mathrm{~g}$ of ATM-la (bars -2, -3 and -4) are available for distribution. Archive material has been retained from some of the batch melting operations but no bar specific archive samples were retained. The glass and archive material is controlled by the MCC Program Material Custodian and is stored in the MCC assigned storage vault in Corridor 7, 308 Building, 300 Area.

TABLE 3.3. Product Summary for ATM-1a Glass

\begin{tabular}{|c|c|c|}
\hline $\begin{array}{l}\text { Initial } \\
\text { I0 No. } \\
\end{array}$ & ID No. & Mass, g \\
\hline U1 & ATM-1a-1 & 38.47 \\
\hline U2 & ATM-1a-2 & 39.87 \\
\hline U3 & ATM-1a-3 & 39.96 \\
\hline U4 & ATM-1a-4 & 25.49 \\
\hline U5 & ATM-1a-5 & 28.59 \\
\hline U6 & ATM-1a-6 & 36.69 \\
\hline U7 & ATM-1a-7 & 30.55 \\
\hline บ8 & ATM-1a-8 & 34.58 \\
\hline U9 & ATM-1a-9 & 37.83 \\
\hline U10 & ATH-1a-10 & 36.76 \\
\hline U11 & ATM-1a-11 & 37.91 \\
\hline U12 & ATM-1a-12 & 40.18 \\
\hline U13 & ATM-1a-13 & 12.40 \\
\hline
\end{tabular}




\subsection{FABRICATION OF ATM-1b}

The fabrication of glass ATM-1b began on January 24, 1983 and was completed by January 28,1983 . A1l work involved in the fabrication of this glass took place in Lab 500, 325 Building, 300 Area. ATM-1b was prepared from crushed type 76-68 glass to which cerium nitrate and depleted uranium oxide powders were added prior to melting.

\subsubsection{Starting Materials}

The glass which served as the feedstock for ATM-1b was MCC-76-68, Lot 1 , bar numbers $2,3,4,5,6,7$, and 8 . The MCC-76-68 glass was produced for PNL by Penberthy Electromelt of Seattle, Washington under purchase order number A2820/A2823AF and received at PNL in September 1980. The average analyzed composition of Lot 1 of the MCC-76-68 glass used for ATM-1b is given in Table 3.1; no specific analyses were conducted on the glass bars actually used in this work. The additives to this base glass for the formulation of ATM-1b included cerium in the form of $\mathrm{Ce}\left(\mathrm{NO}_{3}\right)_{3} \cdot 6 \mathrm{H}_{2} \mathrm{O}$ and depleted uranium in the form of $\mathrm{UO}_{2}$ powder. Both additives were from on-hand stock; the depleted uranium was $0.15 \% 235 \mathrm{y}$ material. No other historical or analytical information is avaitable for these additives.

\subsubsection{Batch Preparation}

Table 3.4 lists the calculated oxide composition of ATM-1b glass. Calculations are based upon a 1 wt\% addition of $\mathrm{CeO}_{2}$ and a 4 wt\% addition of $\mathrm{UO}_{2}$ to glass MCC-76-68 Lot 1 . The batching process was accomplished as follows:

- Seven bars of glass MCC-76-68, Lot 1, as 1isted previously, were crushed, ground and sieved to -60 mesh $(-150 \mu \mathrm{m})$ using a tungsten carbide chamber laboratory disc mill (Angstrom), and Newark stainless steel sieves. All material ( -60 mesh) was combined into a single container and stirred by hand to assure a uniform mixture.

- $3200.0 \mathrm{~g}$ of crushed glass were weighed out and blended with $85.3 \mathrm{~g}$ $\mathrm{Ce}\left(\mathrm{NO}_{3}\right)_{3} \cdot 6 \mathrm{H}_{2} \mathrm{O}$ and $134.7 \mathrm{~g}$ of $\mathrm{UO}_{2}$ powder. This mixture was placed into a hardened porcelain ball mill with burundum grinding media and 
TABLE 3.4. Calculated Bulk Composition

$$
\text { of Glass ATM-1b (a) }
$$

\begin{tabular}{|c|c|}
\hline Oxide & wt $\%$ \\
\hline $\mathrm{Al}_{2} \mathrm{O}_{3}$ & 0.84 \\
\hline $\mathrm{B}_{2} \mathrm{O}_{2}$ & 8.60 \\
\hline $\mathrm{BaO}$ & 0.62 \\
\hline $\mathrm{CaO}$ & 2.28 \\
\hline $\mathrm{CdO}$ & 0.05 \\
\hline $\mathrm{CeO}_{2}$ & 1.00 \\
\hline $\mathrm{Cr}_{2} \mathrm{O}_{3}$ & 0.50 \\
\hline $\operatorname{cs}_{2}{ }^{\circ}$ & 1.20 \\
\hline $\mathrm{Dy}_{2} \mathrm{O}_{3}$ & 0.01 \\
\hline $\mathrm{Eu}_{2} \mathrm{O}_{3}$ & 0.01 \\
\hline $\mathrm{Fe}_{2} \mathrm{O}_{3}$ & 9.03 \\
\hline $\mathrm{Gd}_{2} \mathrm{O}_{3}$ & 0.03 \\
\hline $\mathrm{K}_{2} \mathrm{O}^{0}$ & 0.09 \\
\hline $\mathrm{La}_{2} \mathrm{O}_{3}$ & 4.86 \\
\hline $\mathrm{MgO}$ & 0.18 \\
\hline $\mathrm{MnO}_{2}$ & 0.06 \\
\hline $\mathrm{MoO}_{2}$ & 2.16 \\
\hline $\mathrm{Na}_{2} \mathrm{O}$ & 11.53 \\
\hline $\mathrm{Nd}_{2} \mathrm{O}_{3}$ & 1.64 \\
\hline $\mathrm{NiO}$ & 0.25 \\
\hline$P_{2} 0_{5}$ & 0.56 \\
\hline $\mathrm{SiO}_{2}$ & 40.11 \\
\hline SrO & 0.49 \\
\hline $\mathrm{TiO}_{2}$ & 2.85 \\
\hline $\mathrm{UO}_{2}$ & 4.00 \\
\hline $\operatorname{Zn} 0$ & 4.73 \\
\hline $\mathrm{ZrO}_{2}$ & 2.32 \\
\hline TOTAL & 100.00 \\
\hline
\end{tabular}

(a) Based on addition of uranium and cerium oxides to the oxide concentration values shown in Table 3.1 (Lot 1), and normalization to $100 \%$. See Table 3.1, footnote d. 
processed for 2 hours. At the completion of the milling period the material was removed from the mill and separated from the grinding media .

- The blended batch was divided into three roughly equal sub-batches for the melting operation. Each sub-batch was: 1) me1ted in a Pt crucible by placing about $900 \mathrm{~g}$ into the melting furnace with an air atmosphere which was preheated to $1100^{\circ} \mathrm{C}$; 2) held for 10 minutes and recharged with about $300 \mathrm{~g}$ additional batch; 3) held at $1100^{\circ} \mathrm{C}$ for a total elapsed time of 1.5 hours; 4 ) held at an increased temperature of $1150^{\circ} \mathrm{C}$ for 0.5 hours. The crucible was then removed from the furnace, and the glass mixed by swirling and agitating the crucible. The crucible was returned to the furnace for an additional 10 minutes of soaking before pouring the bars.

- Three separate sub-batches were processed as described above to produce the required bars. Bars were formed by pouring molten glass batch from $1150^{\circ} \mathrm{C}$ into a heated steel bar mold nominally $2.0 \times 2.5 \times$ $17.5 \mathrm{~cm}$, allowing each mold to cool enough to facilitate handing, and placing it into an annealing furnace at $500^{\circ} \mathrm{C}$, where it was held for 2.5 hours and furnace cooled at $\sim 175^{\circ} / \mathrm{hr}$ to $25^{\circ} \mathrm{C}$. The three subbatches produced a total of 14 bars.

\subsubsection{Measurement and Testing Equipment}

Fluke Digital Thermometer, Model No. 2100A, Calib. No. 362-76-06-005 Mettler Balance, Model No. PN5, Calib. No. 362-06-03-069

Mettler Balance, Model No. 323, Calib. No. 362-06-03-067

Mettler Balance, Model No. PC 400, Calib. No. 362-06-03-017

\subsubsection{Other Equipment}

Deltec DT-31-R-SS Furnace

Lindberg Model 51442 Furnace

Angstrom Laboratory Disc mill with Tungsten Carbide Grinding Chamber Jar Mill Assembly, Hardened Porcelain 


\subsubsection{Procedures}

MCC-SP-1 (Draft): Glass Component Preparation

MCC-SP-2 (Draft): Glass Preparation

RWS-325-10: Radiation Work Specification, General Facility

RCP-325-10: Radiation Control Protocol, Laboratory Specific

\subsubsection{Identification System}

Glass bars poured in this fabrication work were individually numbered in accordance with pour order. When the bars were removed from the annealing furnace they were mechanically scribed with a unique number relating to this run. Initially the bars were labeled GLM-1 through GLM-14, but have been relabeled ATM-1b-1 through ATM-1b-14. ATl 14 bars were nominally the same dimensional size with an average mass per bar of $\sim 190 \mathrm{~g}$. Production records for this glass are recorded on Pages 2-3 of PNL Laboratory Record Book BNW-5501. Table 3.5 gives the initial and final bar ID numbers along with the mass.

TABLE 3.5. Product Summary for ATM-1b Glass

$\begin{array}{llc}\begin{array}{l}\text { Initial } \\ \text { ID No. }\end{array} & \text { ID No. } & \text { Mass, g(a) } \\ \text { GLM-1 } & \text { ATM-1b-1 } & 159.6 \\ \text { GLM-2 } & \text { ATM-1b-2 } & 154.5 \\ \text { GLM-3 } & \text { ATM-1b-3 } & 181.6 \\ \text { GLM-4 } & \text { ATM-1b-4 } & 164.7 \\ \text { GLM-5 } & \text { ATM-1b-5 } & 171.6 \\ \text { GLM-6 } & \text { ATM-1b-6 } & 212.0 \\ \text { GLM-7 } & \text { ATM-1b-7 } & 186.4 \\ \text { GLM-8 } & \text { ATM-1b-8 } & 238.0 \\ \text { GLM-9 } & \text { ATM-1b-9 } & 160.7 \\ \text { GLM-10 } & \text { ATM-1b-10 } & 204.0 \\ \text { GLM-11 } & \text { ATM-1b-11 } & 193.0 \\ \text { GLM-12 } & \text { ATM-1b-12 } & 188.2 \\ \text { GLM-13 } & \text { ATM-1b-13 } & 177.9 \\ \text { GLM-14 } & \text { ATM-1b-14 } & 215.3\end{array}$

(a) Some masses are for bars after removal of archive and analytical samples. 


\subsubsection{Material Availability and Storage}

As of August 1985 approximately $1679 \mathrm{~g}$ of ATM-1b are avaflable for distribution in bar form. Archive material has been retained from some of the batch melting operations and a few of the bars have been distributed. The glass and archive material are controlled by the MCC Program Material Custodian and stored in the MCC assigned storage vautt in Corridor 7, 308 Building, 300 Area.

\subsection{FABRICATION OF ATM-1C}

The fabrication of glass ATM-1c began on January 11, 1984 and was completed by February 13, 1984. All work involved in the fabrication of this glass took place in Lab 500, 325 Building, 300 Area. ATM-1c glass was prepared from crushed type 76-68 Glass to which depleted uranium oxide powder was added prior to melting.

\subsubsection{Starting Materials}

The glass which served as the feedstock for ATM-1C was MCC-76-68, Lot 3, bar numbers $249,251,261,264,275$, and 315. The MCC-76-68 glass was produced for PNL by Penberthy Electromelt of Seattle, Washington under purchase order number A2820/A2823AF and received at PNL in September 1980. The average analyzed composition of Lot 3 of the MCC-76-68 Glass used for ATM-1C is given in Table 3.1; no specific analyses were conducted on the glass bars actually used in this work. For the formulation of ATM-1c, uranium was added $i n$ the form of

$\mathrm{UO}_{2}$ powder. The source of the $\mathrm{UO}_{2}$ additive was on-hand stock of $0.15 \% 235 \mathrm{U}$ material. No other historical or analytical information is available for the $\mathrm{UO}_{2}$ additive.

\subsubsection{Batch Preparation}

Table 3.6 lists the requested oxide composition of ATM-1c as stated in the letter of request for NNWSI Glass Composition I (private correspondence, Ballou to Mendel, November 30,1983$)$. The batching process was accomplished as follows:

- Six bars of glass MCC-76-68, Lot 3, as 1isted above, were crushed, ground, and sieved to a -100 mesh $(-150 \mu m)$ using a tungsten carbide disc mill. 
TABLE 3.6. Requested 0xide Composition of Glass ATM-1C (NNWSI Glass I)

\begin{tabular}{|c|c|}
\hline Oxide & $w t \%$ \\
\hline \multicolumn{2}{|l|}{ Inerts } \\
\hline $\mathrm{Al}_{2} \mathrm{O}_{3}$ & 0.49 \\
\hline $\mathrm{B}_{2} \mathrm{O}_{3}$ & 9.17 \\
\hline $\mathrm{CaO}^{\circ}$ & 2.30 \\
\hline $\mathrm{Cr}_{2} \mathrm{O}_{3}$ & 0.34 \\
\hline $\mathrm{Fe}_{2} \mathrm{O}_{3}$ & 8.95 \\
\hline $\mathrm{K}_{2} \mathrm{O}^{\circ}$ & 0.20 \\
\hline $\mathrm{MnO}_{2}$ & 0.08 \\
\hline $\mathrm{Na}_{2} \mathrm{O}$ & 12.9 \\
\hline NiO & 0.20 \\
\hline $\mathrm{P}_{2} \mathrm{O}_{5}$ & 0.68 \\
\hline $\mathrm{SiO}_{2}$ & 41.3 \\
\hline $\mathrm{TiO}_{2}$ & 2.95 \\
\hline $\operatorname{ZnO} 0^{\circ}$ & 4.45 \\
\hline
\end{tabular}

Fission Products

\begin{tabular}{|c|c|}
\hline $\mathrm{Ag}_{2} \mathrm{O}$ & 0.03 \\
\hline $\mathrm{Ba} 0$ & 0.53 \\
\hline $\mathrm{CdO}$ & 0.03 \\
\hline $\mathrm{CeO}_{2}$ & 1.00 \\
\hline $\mathrm{Cs}_{2} \mathrm{O}$ & 1.00 \\
\hline $\mathrm{La}_{2} \mathrm{O}_{3}$ & 1.85 \\
\hline $\mathrm{MoO}_{2}$ & 1.78 \\
\hline $\mathrm{Nd}_{2} \mathrm{O}_{3}$ & 1.30 \\
\hline $\operatorname{Pd} 0$ & 0.57 \\
\hline $\mathrm{Rh}_{2} \mathrm{O}_{3}$ & 0.17 \\
\hline $\mathrm{RuO}_{2}$ & 1.00 \\
\hline $\mathrm{Sm}_{2} \mathrm{O}_{3}$ & 0.12 \\
\hline Sro & 0.40 \\
\hline $\mathrm{TeO}_{2}$ & 0.28 \\
\hline $\mathrm{Y}_{2} \mathrm{O}_{3}$ & 0.21 \\
\hline $\mathrm{ZrO}_{2}$ & 1.62 \\
\hline \multicolumn{2}{|l|}{ Actinides } \\
\hline $\mathrm{UO}_{2}$ & 4.10 \\
\hline TOTAL & 100.00 \\
\hline
\end{tabular}


- $2880.6 \mathrm{~g}$ of the crushed glass were weighed out and blended with $119.4 \mathrm{~g}$ of $\mathrm{UO}_{2}$ powder. This mixture was then placed into a porcelain ball mill with burundum grinding cylinders and milled for 6 hours. Four random samples were taken from the mill and submitted for compositional analysis after the milling operation was completed.

- The average $U_{2}$ analysis of the resulting batch was 4.2 wt\%, slightly higher than the intended concentration. Additional crushed glass from the initial batching step was added to the batch and ball milled for 3 hours. The average $\mathrm{UO}_{2}$ concentration of four random samples from this mixture was 3.98 wt\%.

- The blended material was melted in a Pt crucible in 2 increments of $\sim 1500 \mathrm{~g}$ each, on 2 different days. The melting was conducted at $1150^{\circ} \mathrm{C}$ in an air atmosphere for 0.5 hour at which time it was removed from the furnace, swirled and agitated for stirring and returned to the furnace for an additional 2.5 hours. Six bars were initially poured directly from this batch. The molten glass was poured into a steel mold nominally $1.9 \times 1.9 \times 15 \mathrm{~cm}$, allowed to cool enough to facilitate handling, and placed into an annealing furnace at $500^{\circ} \mathrm{C}$ for 2 hours minimum and furnace cooled at $\sim 50^{\circ} / \mathrm{hr}$ to $25^{\circ} \mathrm{C}$.

- The glass bars produced in the previous step were brown-colored rather than the expected black so the bars were reprocessed as follows. The six bars were coarsely ground and remelted as previously described. Bars cast from this remelting were annealed at $480^{\circ} \mathrm{C}$ for 2 hours and cooled as described previously. The bars from this me1ting were the expected black color.

\subsubsection{Preparation of Special Forms}

Six special forms were requested for delivery to NNWSI (Table 3.7): crushed and sized powder, discs and cylinders with and without stainless steel casings, and tapered cast cylinders. The production of these special forms from the glass fabricated above is described in the following sections.

\subsection{Crushed and Sized Powder. Crushed glass was produced from a} portion of a cast bar by crushing and grinding in a laboratory disc mill using 
TABLE 3.7. Special Form Requirements Requested by NNWSI for MCC ATM-1C Giass

\begin{tabular}{|c|c|c|}
\hline Eorm & Physical Description & $\begin{array}{l}\text { Quantity } \\
\text { Requested }\end{array}$ \\
\hline A & Crushed $g l$ ass, -40 to +80 mesh size & $50 \mathrm{~g}$ \\
\hline B & Discs, $1-c m$ dia. $\times 3$ mall-thick & 80 discs \\
\hline $\mathrm{C}$ & Discs, dimensions as in "B" but with 304 L SS rims & 30 discs \\
\hline D & Cylinder, 1-cm dia. $\times 1-c m$ long & 10 cylinders \\
\hline E & Cylinders, dimensions as in "D" but in 304L SS casing & 10 cylinders \\
\hline $\mathrm{F}$ & Tapered cast cylinders $\left(1^{\circ}\right.$ Taper $), 1.6-c m$ dia. $\times 2-c m$ long & 20 cylinders \\
\hline
\end{tabular}

a tungsten carbide grinding chamber. Material was recovered from the size fraction -40 to +80 mesh (U.S. sieve designation) and packaged for shipment. sizing was performed by manually working the crushed material through the stainless steel sieves with brushing and tapping actions.

3.3.2.1.2 Uncased Discs and Cylinders. Cast bars were cut into $-5 \mathrm{~cm}$ lengths in preparation for core drilling. Cylindrical cores were obtained from the cast bars by diamond core drilling with a water cooled Starlite Industries core drill assembly. These cores were then cut to size using a Buehler Isomet low speed saw with a low concentration diamond wafering blade and water as the cutting media. Discs were nominally 3-mm thick by 1-cm diameter; whole cylinders were $1-c m$ long by $1-c m$ diameter. Eighty discs and 10 cylinders were produced.

\subsection{Stainless-Steel Clad Discs and Cylinders. Scraps and pieces} from the production of core-drilled samples and cutting remains were used for an additional melt to cast glass inside 304L stainless-steel tubing. Molds were fabricated by cutting $5-\mathrm{cm}$ long sections from seamless $304 \mathrm{~L}$ stainlesssteel tubing $1 \mathrm{~cm}$ in outside diameter. The nominal wall thickness of this tubing was 0.9 mik. The glass material was melted at $1250^{\circ} \mathrm{C}$ for approximately 30 minutes and poured into the tubular molds which had been preheated to $480^{\circ} \mathrm{C}$. After casting was complete the tubes were annealed at $480^{\circ} \mathrm{C}$ for a minimum of 2 hours and furnace cooled to $25^{\circ} \mathrm{C}$. The tubular castings were cut to size using a Buehler I somet low speed saw with a low concentration diamond 
wafering blade and water as the cutting medium. Discs were nominally 3-mm thick by $1-\mathrm{cm}$ diameter, while cylinders were $1-\mathrm{cm}$ long by $1-\mathrm{cm}$ diameter. Thirty discs and 10 cylinders were produced.

3.3.2.1.4 Tapered Cast Cylinders. The following fabrication outline lists the steps that were followed to produce the tapered cast cylinders (Form F) of ATM-1C glass. The required cast glass dimensions were specified by NNWSI (private correspondence, Bates to Mellinger, May 17, 1984). The casting crucibles were specified by NNWSI as "a Pt 5\% Au mold, ...a modified J. Lawrence Smith crucible from Englehard Industries, per ANL purchase order 055090." The crucibles for this work were obtained from Johnson Matthey Co. on PNL P.0. J 7160 ARO using the same specification as above with the concurrence of NNWSI staff.

- Previously melted glass bars were remelted to form the feed material for the present castings. Melting was conducted in a Pt crucible at $1150-1200^{\circ} \mathrm{C}$ in an air atmosphere, a temperature sufficient to produce satisfactory casting behavior. Residence time at temperature was approximately 30 minutes.

- Molten glass was poured into the casting crucible mold which had been preheated to $500^{\circ} \mathrm{C}$; the mold was completely enclosed in a mold/ firebrick assembly. The assembly was transferred to an annealing furnace and held at $500^{\circ} \mathrm{C}$ for 30 minutes; cooled at approximately $100^{\circ} \mathrm{C} / \mathrm{h}$ to $350^{\circ} \mathrm{C}$; removed from the firebrick and allowed to cool to room temperature.

- The glass casting was removed from the crucible by inverting the crucible and gently shaking and tapping the bottom. Twisting of the glass casting in the crucible was avoided to minimize glass surface scratching.

- Finished samples were a tapered right-circular cylinder cut to a length of $2.00 \pm 0.1 \mathrm{~cm}$ with parallel cut ends normal to the cylinder axis. Cutting to dimensions was performed on a Buehler low speed cut-off saw using a low concentration diamond blade (No. 11-4254), at a speed setting of " 6 " and water as the cutting fluid. A specially 
padded double jaw chuck was used to hold the samples for the entire cutting operation. A ring gauge was used to establish the first cut, and a dimensional shift of the chuck and sample was made to position the sample for the second cut.

\title{
3.3.3 Measurement and Testing Equipment
}

Fluke Digital Thermometer, Model No. 2100A, Calib. \#362-79-06-005

Mettler Balance, Model No. PC 400, Calib. \$362-06-01-017

\subsubsection{Other Equipment}

Deltec DT-31-1255 Furnace

Norton Jar Mil1

Angstrom Disc Mill w/Tungsten Carbide Chamber

Cut-off Saw, Buehler Isomet

Core Drill, Starlite Industries

\subsubsection{Procedures}

\author{
MCC-SP-1 (Draft): GTass component Preparation \\ MCC-SP-2 (Draft): Glass Preparation \\ RWS-325-10: Radiation Work Specification, General Facility \\ RCP-325-10: Radiation Control Protocol, Laboratory
}

\subsubsection{Identification System}

Glass bars produced in this fabrication work were not individually numbered or otherwise identified individually as they were poured. Bars were subsequently numbered in random order for purposes of identification. No other similar activities occurred in the lab during this period, and the identity of the material was maintained by collection and storage in a singular location or container. This container was marked "MCC:ATM-1C GLASS." Fourteen glass bars were produced from the batch of ATM-1C material, some of which were subsequently core drilled to produce cylinders and discs, crushed to produce powdered material, and remelted to produce special castings. Production records for this glass are recorded on Pages 9-11 of PNL Laboratory Record Book BNW-5501. 


\subsubsection{Material Availability and Storage}

A1l ATM-1c glass was distributed to NNWSI, and no material is available for general distribution. Archive samples remaining from the initial as-cast bars are controlled by the MCC Program Material custodian and are stored in the MCC assigned storage vault in Corridor 7, 308 8uilding, 300 Area. No archive samples were retafned for the special NNWSI samples. 


\subsection{CHARACTERIZATION}

Characterization of the three lots of ATM-1 glass consisted of bulk physical measurements, chemical analysis, scanning electron microscopy (SEM), and $x$-ray diffraction (XRD) analysis. The results of these analyses on ATM-1a, $-1 b$, and $-1 c$ are detailed in the following sections according to analytical procedure.

\subsection{BULK DENSITY MEASUREMENTS}

Bulk density was determined on three samples taken from each glass lot by ASTM procedure $C$ 693-74, "Standard Method for Density of Glass by Buoyancy." The technique was modified by using 2-g samples instead of the 20-g samples specified. Density samples were prepared by removing a section from the end of randomly selected bars and triming of all cast surfaces using a Buehler s somet saw, using a low concentration diamond wafering blade and water coolant. Hefore measurement, all samples were cleaned twice in acetone in an ultrasonic cleaner and dried at approximately $100^{\circ} \mathrm{C}$. Table 4.1 summarizes the density measurements.

TABLE 4.1. Measured Bulk Density of ATM-1 Glass

\begin{tabular}{|c|c|c|}
\hline $\begin{array}{l}\text { G] ass } \\
\text { Lot }\end{array}$ & $\begin{array}{l}\text { Identity of } \\
\text { Bars Used } \\
\text { for Specimens } \\
\end{array}$ & $\begin{array}{l}\text { Average Measurȩd } \\
\text { Density, } \mathrm{g} / \mathrm{cm}^{3}\end{array}$ \\
\hline ATM-la & $3,4,5$ & $3.025 \pm 0.002$ \\
\hline ATM-1b & $1,9,14$ & $3.045 \pm 0.003$ \\
\hline ATM-1C & $5,7,8$ & $3.017 \pm 0.003$ \\
\hline
\end{tabular}




\subsection{CHEMICAL ANALYSIS}

Chemical analysis was performed by Inductively-Coupled Argon Plasma Atomic Emission Spectroscopy (ICP) for the majority of the elements. Uranium was analyzed by pulsed laser fluorometry and cesium by Atomic Absorption Spectroscopy. ICP analys is was performed on an ARL-3650 spectrometer, laser fluorometry was performed on a Scintrex Model 3-A Uranium Analyzer and AA was performed on a Perkin-Elmer Model 305 spectrometer. Solid analytical samples were ground to -100 mesh $(-150 \mu \mathrm{m})$ duplicate samples fused with $\mathrm{KOH}$ and with $\mathrm{Na}_{2} \mathrm{O}_{2}$, and dissolved in dilute $\mathrm{HCl}$ to a known volume for analysis.

The results of the chemical analysis of 12 samples from each glass batch are given in Table 4.2. Analysis of ATM-la glass was conducted on randomly selected remnants of the bars used to prepare test specimens. For ATM-1b glass, 12 samples for analysis were taken from individual bars (number 1, 2, 3, $4,5,7,9,12$, and 13). Similariy, 9 of the unnumbered ATM-1c bars were used to provide 12 analytical samples for analysis.

It should be noted that the satisfactory precision shown for individual element analyses indicates that all 3 glass lots are homogeneous, but the summation of concentrations is significantly less than $100 \%$, even considering probable concentrations of elements not analyzed. Therefore, the accuracy of individual values is uncertain, and simple normalization of all data equally to achieve $100 \%$ is not justified. Additional analyses by independent laboratories and methods are in progress.

\subsection{MICROSCOPIC EXAMINATION}

Scanning electron microscopy was conducted on four fracture samples of each of the glass lots prepared from sections removed from the ends of three of the bars (one end from two bars, two ends from one bar) used for chemical analysis. Figure 4.1 illustrates typical microstructures observed in ATM-1 glass. The microscopy showed a random distribution of small voids or bubbles ( 1 1 m nominal diameter) as well as a minor microstructural features, apparently crystalline and high in Fe, probably a spinel. SEM examination was performed on a JEOL Model JSM 35C Scanning Electron Microscope with a Tracor Northeqn Model TN-2000 Energy Dispersive Spectrometer. 
TABLE 4.2. Analyzed Composition of ATM-1 Glass(a)

\begin{tabular}{|c|c|c|c|c|c|c|}
\hline \multirow[b]{2}{*}{ Oxide } & \multicolumn{2}{|c|}{ ATM-1a } & \multicolumn{2}{|c|}{ ATM-1b } & \multicolumn{2}{|c|}{ ATM-1C } \\
\hline & $w t \%$ & $\begin{array}{l}\text { Standard } \\
\text { Deviation }\end{array}$ & $w t \%$ & $\begin{array}{l}\text { Standard } \\
\text { Deviation }\end{array}$ & $w t \%$ & $\begin{array}{l}\text { Standard } \\
\text { Deviation }\end{array}$ \\
\hline $\mathrm{Ag}_{2} \mathrm{O}$ & NA & -- & NA & -- & NA & -- \\
\hline $\mathrm{Al}_{2} \mathrm{O}_{3}$ & 0.64 & 0.03 & 0.85 & 0.02 & 0.58 & 0.02 \\
\hline $\mathrm{B}_{2} \mathrm{O}_{3}$ & 8.47 & 0.31 & 8.55 & 0.08 & 9.07 & 0.07 \\
\hline $\mathrm{BaO}$ & 0.50 & 0.02 & 0.62 & 0.00 & 0.54 & 0.00 \\
\hline $\mathrm{CaO}$ & 1.99 & 0.99 & 2.11 & 0.03 & 2.23 & 0.02 \\
\hline $\mathrm{CdO}$ & 0.04 & 0.00 & 0.04 & 0.00 & 0.04 & 0.00 \\
\hline $\mathrm{CeO}_{2}$ & 0.88 & 0.03 & 0.97 & 0.09 & 0.90 & 0.03 \\
\hline $\mathrm{Cr}_{2} \mathrm{O}_{3}$ & 0.39 & 0.02 & 0.45 & 0.04 & 0.42 & 0.01 \\
\hline $\mathrm{Cs}_{2} \mathrm{O}^{\circ}$ & 0.71 & 0.04 & 0.77 & 0.02 & 0.78 & 0.05 \\
\hline $\mathrm{Dy}_{2} \mathrm{O}_{3}$ & $<0 \mathrm{~L}, 0.01$ & -- & $<0 \mathrm{~L}, 0.01$ & -- & $<\mathrm{DL}, 0.01$ & -- \\
\hline $\mathrm{Eu}_{2} \mathrm{O}_{3}$ & NA & -- & NA & -- & NA & -- \\
\hline $\mathrm{Fe}_{2} \mathrm{O}_{3}$ & 8.16 & 0.29 & 8.16 & 0.04 & 8.70 & 0.05 \\
\hline $\mathrm{Gd}_{2} \mathrm{O}_{3}$ & $<D L, 0.03$ & -- & $<\mathrm{DL}, 0.03$ & -- & $<\mathrm{DL}, 0.03$ & -- \\
\hline $\mathrm{K}_{2} \mathrm{O}^{\circ}$ & 0.56 & 0.29 & 0.56 & 0.15 & 0.73 & 0.13 \\
\hline $\mathrm{La}_{2} \mathrm{O}_{3}$ & 4.00 & 0.19 & 5.07 & 0.02 & 4.39 & 0.03 \\
\hline $\mathrm{MgO}$ & 0.30 & 0.00 & 0.30 & 0.01 & 0.24 & 0.02 \\
\hline $\mathrm{MnO}_{2}$ & 0.03 & 0.00 & 0.03 & 0.00 & 0.03 & 0.00 \\
\hline $\mathrm{MoO}_{3}$ & 1.72 & 0.08 & 1.99 & 0.03 & 1.82 & 0.01 \\
\hline $\mathrm{Na}_{2} \mathrm{O}$ & 10.14 & 0.43 & 9.66 & 0.08 & 10.51 & 0.10 \\
\hline $\mathrm{Nd}_{2} \mathrm{O}_{3}$ & 1.34 & 0.05 & 1.61 & 0.03 & 1.42 & 0.01 \\
\hline $\mathrm{NiO}$ & 0.18 & 0.01 & 0.22 & 0.03 & 0.20 & 0.01 \\
\hline $\mathrm{P}_{2} \mathrm{O}_{5}$ & 0.63 & 0.05 & 0.60 & 0.06 & 0.60 & 0.06 \\
\hline $\mathrm{PdO} 0^{\circ}$ & NA & -- & NA & -- & NA & -- \\
\hline $\mathrm{Rh}_{2} \mathrm{O}_{3}$ & NA & -- & NA & - & NA & -- \\
\hline $\mathrm{RuO}_{2}$ & NA & -- & NA & -- & NA & -- \\
\hline $\mathrm{SiO}_{2}^{2}$ & 38.73 & 1.35 & 40.50 & 0.28 & 41.2 & 0.03 \\
\hline $\mathrm{Sm}_{2} \overline{\mathrm{O}}_{3}$ & NA & -- & NA & -- & NA & - \\
\hline Sro & 0.37 & 0.01 & 0.46 & 0.01 & 0.40 & 0.005 \\
\hline $\mathrm{TeO}_{2}$ & NA & -- & NA & -- & NA & -- \\
\hline $\mathrm{TiO}_{2}^{2}$ & 2.62 & 0.09 & 2.60 & 0.01 & 2.82 & 0.02 \\
\hline $\mathrm{UO}_{2}$ & 3.98 & 0.11 & 4.16 & 0.08 & 4.02 & 0.08 \\
\hline$Y_{2} \hat{O}_{3}$ & NA & - & $N A$ & -- & $\mathrm{NA}$ & -- \\
\hline $\operatorname{Zn} 0^{\circ}$ & 4.15 & 0.15 & 4.34 & 0.03 & 4.46 & 0.04 \\
\hline $\mathrm{ZrO}_{2}$ & 1.46 & 0.05 & 1.88 & 0.06 & 1.54 & 0.09 \\
\hline Total & 91.99 & & 96.50 & & 97.64 & \\
\hline
\end{tabular}

\footnotetext{
(a) Based on analysis of 12 random samples for each batch; standard deviations for an individual analysis. $N A=$ Not analyzed.

$\angle D L=$ Below the detection limit indicated.
} 


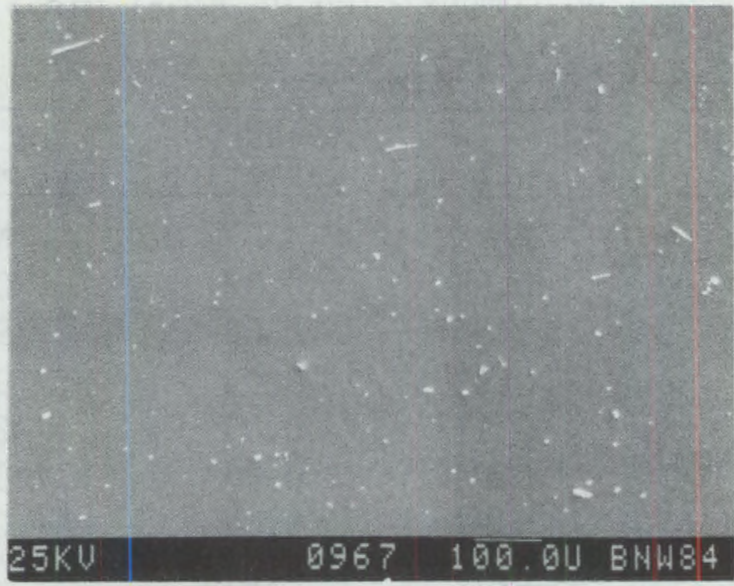

ATM-1a
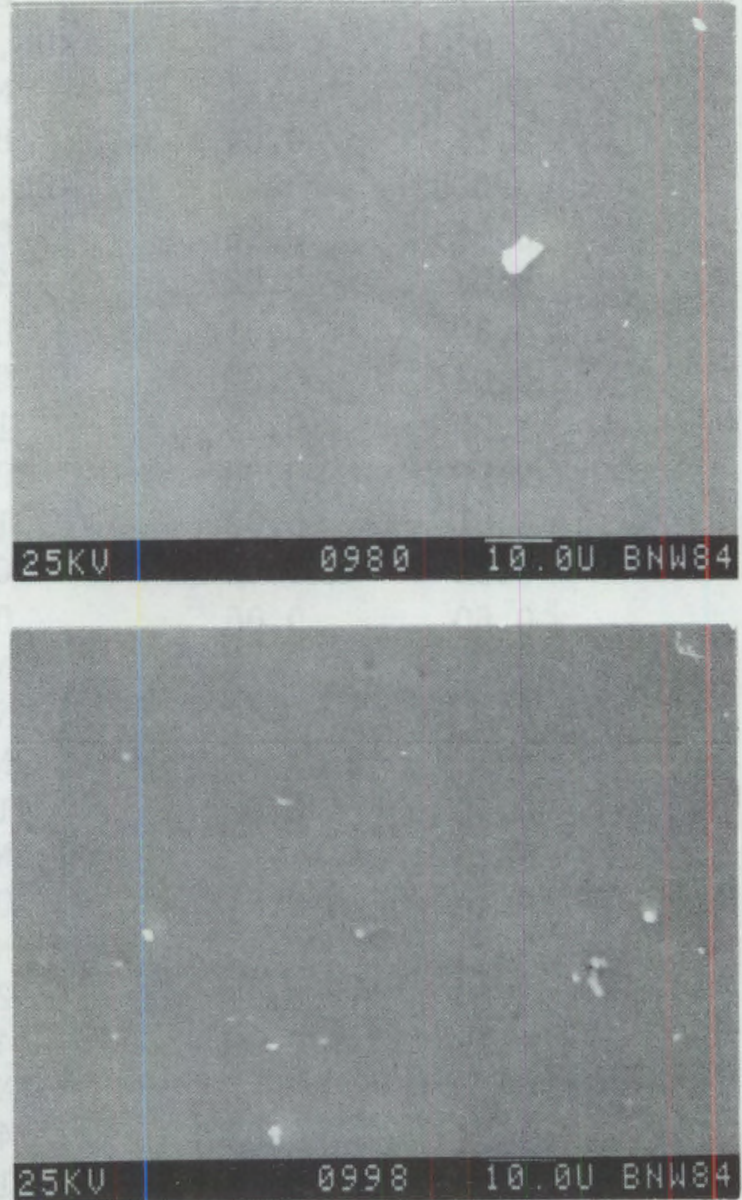

ATM-1C

FIGURE 4.1. Typical Microstructure of Glass ATM-1 (scanning electron micrographs of fracture surfaces; bar at the bottom of photo represents $100 \mu \mathrm{m}$ for ATM-1a and 10 um for ATM-1b and 1c) 


\subsection{X-RAY DIFFRACTION ANALYSIS}

Four samples of each glass batch were prepared for standard powder $x$-ray diffraction (XRD) analysis. As before, two samples were obtained from a single end of two bars, while two more samples were obtained from both ends of one bar. Solid samples were ground and sieved to -200 mesh (-75 $\mu \mathrm{m})$ and analyzed on a Phillips Model WCDU X-Ray Diffractometer. No crystalline features were observed in ATM-la, while two samples of ATM-1B showed trace levels of an ironchrome spinel phase. ATM-1C also showed the spinel phase present in all the samples analyzed. Concentration of the spinel in ATM-1b and ATM-1c were estimated at $3-5 \mathrm{wt} \%$; the detection limit of this phase in a glassy matrix using XRD is estimated to be about 3 wt\%. Table 4.3 is a summary of the XRD observations.

TABLE 4.3. Summary of X-ray Diffraction Analys is of ATM-1 Conditions Used: Instrument - Philips Model WCDU Radiation - Cu Ka

Scan Range - 10 to $60^{\circ} 2 \theta$ o $1 / 4^{\circ} / \mathrm{min}$

Glass Type observations (a)

ATM-1a No crystalline phases evident in 4 samples

ATM-10 1 sample: spinel peaks (220) and (311); sharp, well defined, weak

1 sample: trace of (311) spinel; broad, poorly defined

2 samples: no crystalline phases

ATM-1C 2 samples: resolvable spinel peaks (220) and (311)

1 sample: spinel peaks appear to be present but not reproducible

1 sample: trace of (311) peak only

(a) All spectra were superimposed on the high background typical of glass $x$-ray spectra. 


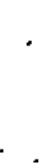




\subsection{REFERENCES}

Mellinger, G. B., and J. L. Oaniel. 1984. Approved Reference and Testing Materials for Use in Nuclear Waste Management Research and Development Programs. PNL-4955-2, Pacific Northwest Laboratory, Richland, Washington.

Mende1, J. E. et al. 1977. Annual Report of the Characteristics of High-Level Waste Glasses. BNWL-2252, Pacific Northwest Laboratory, Richland, Washington. 


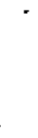




\section{DISTRIBUTION}

No. of

Copies

OFFSITE

1. A. Coleman

DCE Headquarters

NE -25

Washington, DC 20545

J. A. Turi

DOE Headquarters

NE -25

Washington, DC 20545

R. D. Walton, Jr.

DDE Headquarters

DP-123, GTN

Washington, OC 20545

M. W. Frei

DOE Headquarters

$\mathrm{RW}-23$

Washington, DC 20545

30 DOE Technica? Information Center

Michael 1. Bell

Nuclear Regulatory Commission

Washington, DC 20555

K. S. Kin

Nuclear Regulatory Commission

Washington, DC 20555

E. Wicks

Nuclear ReguTatory Commission

Washington, DC 20555

H. P. R. Frederikse

U. S. Department of Commerce

National Bureau of Standards

Washington, DC 20234
No. of

Copies

Dr. W. P. Reed

Office of Measurements for Nuclear Technology

National Bureau of Standards

Physics Building, Ronm B3?0

Washington, DC 20234

Dr. Charles G. Interrante

Corrosion Group, Metallurgy Division

Nationa 1 Bureau of Standards

MATLS B-254

Gaithersburg, MD 20899

R. Clayton

Enrico Fermi Institute

5640 S. Ellis

Chicago, IL 60647

K. Golliher

DOE Albuquerque Operations Office P. 0. Box 5400

Albuquerque, NM 87115

M. McFadden

DOE Albuquerque 0perations office

P. 0. Box 5400

Albuquerque, NM 87115

John Van Cieve

DOE Oak Ridge Operations office

P. D. Box X

Oak Ridge, TN 37830

W. J. Brumley

DOE Savannah River Dperations Office

P. 0. Box A

Aiken, SC 29801

J. C. Haugen

DOE Chicago Operations Office

9800 South Cass Avenue

Argonne, IL 60439 
No. of

Copies

J. 0. Neff

U.S. Department of Energy

Salt Repository Project Office

505 King Avenue

Columbus, $\mathrm{OH} 43201$

K. K. Wu

U.S. Department of Energy

Salt Repository Project Office

$505 \mathrm{King}$ Avenue

Columbus, $\mathrm{OH} 43201$

J. K. Bates

Argonne National Laboratory

9700 South Cass Avenue

Argonne, IL 60439

W. B. Seefeldt

Argonne National Laboratory

9700 South Cass Avenue

Argonne, IL 60439

M. J. Steindler

Argonne National Laboratory

9700 South Cass Avenue

Argonne, IL 60439

S. Vogler

Argonne National Laboratory

9700 South Cass Avenue

Argonne, IL 60439

A. A. Baver

Office of Crystalline Repository Development

Battelle Project Management Division

P. 0. Box 16595

Columbus, $\mathrm{OH}$ 43216-6595
No. of

Copies
D. E. Clark

Office of Nuclear Waste Isolation

Battelle Project Management Division

P. 0. Box 16594

Columbus, $\mathrm{OH}$ 43216-6594

D. P. Moak

Office of Nuclear Waste Isolation

Battelle Project Management Division

P. 0. Box 16594

Columbus, $\mathrm{OH}$ 43216-6594

Beveriy Rawles

BMI-Library

505 King Avenue

Columbus, $\mathrm{OH} 43210$

P. Colombo

Brookhaven National Laboratory

Upton, NY 11973

M. 3. Plodinec

E.I. duPont deNemours and $C_{0}$., Inc. Savannah River Laboratory

Aiken, SC 29808-0001

G. G. Wicks

E.I. duPont deNemours and Co., Inc. Savannah River Laboratory

Aiken, SC 29808-0001

R. M. Neilson, Jr.

EG\&G

P. 0. Box 1625

Idaho Falls, ID 83415 
No. of

Copies

J. R. Berreth

Westinghouse Idaho Nuclear Co. P. 0. Box 4000

Idaho Falls, ID 83403

F. Bazan

Lawrence Livermore National Laboratory

University of California

P. 0. Box 808

Livermore, CA 94550

D. Isherwood

Lawrence Livemore Nationa? Laboratory

University of California

P. 0. Box 808

Livermore, CA 94550

J. E. Harrar

Lawrence Livermore National laboratory

University of California

P. 0. Box 808

Livermore, CA 94550

L. Ballou

Lawrence Livermore National l.aboratory

University of California

P. 0. Box 808

Livermore, CA 94550

R. D. McCright

Lawrence Livermore National Laboratory

University of California

P. 0. Box 808

Livermore, CA 94550
No. of

Copies

V. Oversby

Lawrence Livermore National Laboratory

University of California

P. 0. Box 808

Livermore, CA 94550

H. W. Godbee

Union Carbide Corporation

Oak Ridge National Laboratory

P. 0. Box $Y$

Oak Ridge, TN 37830

Dr. Leslie R. Dole

Oak Ridge National Laboratory

P. 0 . Box $X$

Oak Ridge, TN 37831

A. B. Harker

Rockwel! International Science Center

P. 0. Box 1085

1049 Camino Dos Rios

Thousand Oaks, CA 91360

L. Brush

Sandia Nationa? Laboratory

P. 0. Box 5800

Albuquerque, NM 87107

R. Diegle

Sandia National Laboratory

P. 0. Box 5800

Albuquerque, NM 87107

M. M. Madsen

Div. 6323

Sandia National Laboratory

P. 0. Box 5800

Albuquerque, NM 87815 
No. of

Copies

M. Magnani

Sandia Nationa? Laboratory

P. 0. Box 5800

Albuquerque, NM 87107

M. A. Molecke

Sandia National Laboratory

P. $0.80 \times 5800$

A1buquerque, NM 87107

\section{A. Barkatt}

Vitreous State Laboratory

Keane $\mathrm{Ha}$ ?]

Catholic University of America

Washington, DC 20064

P. B. Macedo

Vitreous State Laboratory

Keane Hall

Catholic University of America

P. 0. Box 1663

Washington, DC 20064

D. E. Clark

University of Florida

Department of Material Science and Engineering

College of Engineering

Gainesville, FL 32611

H. Birnbaum

308 Metal lurgy

University of 11 linois

Urbana, IL 61801

Dr. Abraham Lerman

Department of Geologic Science Northwestern University

Evanston, IL 60201
No. of

Copies

R. L. Coble

Massachusetts Institute of Technology

B?dg. 13, Room 4062

77 Massachusetts Avenue

Cambridge, MA 02139

W. W. Gerberich

Department of Chemical Engineering and Materials Science

151 Amundson Hall

University of Minnesota

Minneapolis, MN 55455

D. G. Brookins

Department of Geology

University of New Mexico

A1buquerque, NM 87131

W. B. White

Pennsylvania State University

University Park, PA 16802

H. Barnes

Pennsylvania State University

University Park, PA 16802

J. M. Pope

West Valley Nuclear Services

Co., inc.

P. 0. Box 191

West Valley, NY 14171-0191

J. E. Burke

33 Forest Road

Burnt Hi11s, NY 12027

S. Clayton

National Energy Information Center 3500 Central Avenue S.E.

Albuquerque, NM 87131 
No. of

$\underline{\text { Copies }}$

G. Mac Zura

Alcoa Laboratories

Alcoa Technical Center

Alcoa Center, PA 15069

ONSITE

6 DOE Richland Operations Office

E. A. Bracken

P. E. Lamont

M. J. Plahuta

M. W. Shupe

J. D. White

J. K. W. Wukelic

7 Rockwell Hanford Operations

E. H. Randklev

P. F. Salter

W. W. Schulz

M. J. Smith

D. A. Turner

D. D. Wodrich

R. P. Anantatmula

5 Westinghouse Hanford Company

R. E. Einziger

R. L. Knecht

J. J. McCown

H. D. Smith

C. N. Wilson
No. of

Copies

61

Pacific Northwest Laboratory

K. H. Abel

R. D. Allen

M. J. Apted

J. 0. Barner

D. J. Bradley

W. M. Bowen

H. C. Burkholder

D. G. Coles

J. L. Daniel (20)

J. R. Divine

F. N. Hodges

C. H. Kindle

C. A. Knox

M. R. Kreiter

K. M. Krupka

W. L. Kuhn

J. M. Latkovich

J. L. McElroy

G. L. McVay

G. B. Mellinger

J. E. Mende 1

M. D. Merz

S. G. Pitman

W. A. Ross

R. J. Serne

S. C. Slate

J. W. Thielman

J. W. Wald (5)

$R$. Wang

R. E. Westerman

P. L. Whiting

Publishing Coordination (2)

Technical Information (5) 


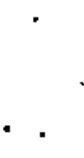

. 